\title{
Hepatoma presenting as craniospinal metastasis: analysis of sixteen cases
}

\author{
Jen-Pei Lee
}

\begin{abstract}
Sixteen cases of hepatoma presenting as craniospinal metastasis without obvious hepatic involvement were reviewed. Metastatic spread of hepatoma to the cerebrum was found in one case, to the cranium in six cases, and to the vertebrae in nine cases. All of these cases had mildly abnormal liver function when first evaluated. Of those patients with hepatoma, $56 \%$ had evidence of hepatomegaly. Alpha fetoprotein was present, at levels greater than $320 \mathrm{ng} / \mathrm{ml}$, in $69 \%$. Ninety four per cent died of the primary liver disease within one year. For any patient who develops craniospinal metastasis of unknown origin in a geographical area where hepatoma is a common disease, hepatoma should be considered in the differential diagnosis.
\end{abstract}

$(\Im$ Neurol Neurosurg Psychiatry 1992;55:1037-1039)

Hepatoma has a widely varying incidence in different parts of the world. It is at least 10 times higher in South African black groups and Southeast Chinese than in North Americans and Europeans. ${ }^{1}$ In Taiwan, hepatoma is one of the most common malignancies. In postmortem examinations, it represents $5.5 \%$ of the total and $21.8 \%$ of all malignancies. ${ }^{1}$

Most patients with hepatoma present with hepatomegaly, right upper quadrant pain, or an abdominal mass. ${ }^{2}$ On rare occasions, the patients may have initial symptoms related exclusively to the metastatic disease. In this paper, we describe our experience of 16 patients with hepatoma who presented primarily as craniospinal metastasis without obvious hepatic involvement.

\section{Materials and methods}

A retrospective review of the clinical records of 768 patients with primary hepatoma admitted to Chang Gung Memorial Hospital between July 1981 and June 1988 produced 16 patients who initially presented with neurological symptoms caused by craniospinal metastasis. None of these patients had any obvious hepatic symptoms suggestive of primary liver diseases. The final diagnosis was confirmed by histological examination of operative or biopsied specimens from the site of metastasis which caused the neurological complication. There were 13 men and three women, ranging in age from 26 to 60 (mean 44) years. On the basis of site of metastasis, three groups were found: cerebral, cranial, and vertebral, including one, six, and nine cases respectively. Routine liver function tests and a serological test for hepatitis B surface antigen were done on the first day of admission. Additional liver investigations, including serum alpha fetoprotein (AFP) measurements, liver-spleen CT, abdominal sonography, or coeliac angiogram, were performed after the tissue diagnosis had been made. AFP was classified as "positive" if the level was above $320 \mathrm{ng} / \mathrm{ml}$.

\section{Results}

\section{Clinical features}

The clinical manifestations and the site of metastasis in each patient are listed in the table.

In the cerebral group, the patient presented with progressive weakness and numbness in the left arm, followed by intracranial haemorrhage and disturbed consciousness. Tumour bleeding was confirmed by histological study.

In the cranial group, two different sites of metastasis were found, the calvarium and the base of the skull; there were three instances of each. Two of the three patients with metastasis to the calvarium had a progressively enlarging mass in the vertex. During the operation, no intradural invasion was found. The third patient had symptoms and signs suggestive of intracranial tumour, and intradural extension and parenchymal involvement of the brain were demonstrated. All three patients with metastasis to the base of the skull presented with symptoms of cranial nerve involvement. Those with retrobulbar or parasellar involvement developed diplopia, ptosis and limitation of eye movements. The patient with metastasis to the jugular fossa and hypoglossal canal manifestated dysarthria and tongue atrophy.

In the vertebral group, one metastasis was in the cervical spine, two in the thoracic region, four in the lumbar vertebrae, and two in the sacrum. All of these patients experienced back pain or neck pain as the first symptom, followed by symptoms of spinal cord involvement. The patient with cervical involvement presented with arm weakness. The patients with lesions in the thoracic region had progressive paraparesis as the predominant symptom. With metastasis of the lumbar vertebrae, all except one patient presented with paraparesis or sphincter problems, or both. This patient's symptoms mimicked a herniated intervertebral disc. With lesions in the sacral region, sphincter problems were the main complaint.

Hepatomegaly is an important symptom 


\begin{tabular}{|c|c|c|c|c|c|c|}
\hline Case no & Age & Sex & Presenting symptoms & Site of metastasis & Hepatomegaly & $\begin{array}{l}\text { Survival (from the } \\
\text { onset of symptoms) } \\
\text { (months) }\end{array}$ \\
\hline Cerebral & 59 & $\mathbf{M}$ & $\begin{array}{l}\text { Left arm weakness and numbness for one week, sudden } \\
\text { onset of headache with left hemiplegia and disturbed } \\
\text { consciousness }\end{array}$ & $\begin{array}{l}\text { Brain parenchyma (right } \\
\text { frontotemporal pareital) with } \\
\text { intracranial haemorrhage }\end{array}$ & - & 2 \\
\hline $\begin{array}{l}\text { Cranial } \\
2\end{array}$ & 58 & $\mathbf{F}$ & $\begin{array}{l}\text { Progressive enlarging scalp mass over vertex for } 4 \\
\text { months }\end{array}$ & $\begin{array}{l}\text { Calvarium, dura, brain } \\
\text { parenchyma }\end{array}$ & - & 10 \\
\hline 3 & 48 & $\mathbf{F}$ & $\begin{array}{l}\text { Progressive enlarging scalp mass over the left parietal } \\
\text { and right frontal region for } 6 \text { months }\end{array}$ & Calvarium & + & 8 \\
\hline 4 & 36 & $\mathbf{M}$ & $\begin{array}{l}\text { Progressive enlarging scalp mass in right occipital } \\
\text { region for } 2 \text { months }\end{array}$ & Calvarium & + & 3 \\
\hline 5 & 60 & $\mathbf{M}$ & $\begin{array}{l}\text { Diplopia and proptosis for } 2 \text { months. Ophthalmoplegia } \\
\text { for } 1 \text { month }\end{array}$ & Skull base (retrobulbar) & + & 7 \\
\hline 6 & 54 & $\mathbf{M}$ & $\begin{array}{l}\text { Progressive dysarthria and atrophy of left tongue for } 2 \\
\text { months }\end{array}$ & $\begin{array}{l}\text { Skull base (jugular fossa } \\
\text { hypoglossal canal) }\end{array}$ & - & 4 \\
\hline 7 & 47 & $\mathbf{M}$ & $\begin{array}{l}\text { Right hemicrania for } 3 \text { months blurred vision with } \\
\text { ptosis and limitation of eye movement (OD) } \\
\text { numbness on the right forehead for one month }\end{array}$ & Skull base (parasella) & + & 6 \\
\hline $\begin{array}{l}\text { Vertebral } \\
8\end{array}$ & 50 & $\mathbf{M}$ & $\begin{array}{l}\text { Root pain over right C7. Right arm weakness for } 2 \\
\text { weeks }\end{array}$ & C7 & - & 2 \\
\hline 9 & 44 & $\mathbf{M}$ & $\begin{array}{l}\text { Back pain for } 2 \text { months. Progressive paraparesis for } 2 \\
\text { months }\end{array}$ & $\mathrm{T} 7$ & + & 7 \\
\hline $\begin{array}{l}10 \\
11\end{array}$ & $\begin{array}{l}38 \\
60\end{array}$ & $\begin{array}{l}\mathbf{M} \\
\mathbf{M}\end{array}$ & $\begin{array}{l}\text { Lower back pain for } 6 \text { weeks. Paraparesis for } 3 \text { weeks } \\
\text { Low back pain for } 4 \text { months. Progressive paraparesis }\end{array}$ & $\begin{array}{l}\mathrm{T} 8,9 \\
\mathrm{~L} 1,2\end{array}$ & $\begin{array}{l}+ \\
-\end{array}$ & $\begin{array}{l}7 \\
9\end{array}$ \\
\hline 12 & 50 & $\mathrm{~F}$ & $\begin{array}{l}\text { Lower back pain with progressive paraparesis for } 2 \\
\text { months }\end{array}$ & $\mathrm{L} 2,3$ & - & 4 \\
\hline 13 & 46 & $\mathbf{M}$ & $\begin{array}{l}\text { Lower back pain with numbness over left leg for } 2 \\
\text { months, left sciatica for } 2 \text { weeks }\end{array}$ & L4 & - & 7 \\
\hline 14 & 31 & $\mathbf{M}$ & $\begin{array}{l}\text { Lower back pain with left sciatica for } 3 \text { months. } \\
\text { Spincter disturbance for } 2 \text { weeks }\end{array}$ & L5 & + & 4 \\
\hline 15 & 26 & $\mathbf{M}$ & $\begin{array}{l}\text { Buttock pain radiating to right thigh for } 2 \text { months, } \\
\text { sphincter disturbance for } 1 \text { month }\end{array}$ & Sacrum & + & 13 \\
\hline 16 & 50 & $\mathbf{M}$ & Buttock pain with sphincter disturbance for 3 months & Sacrum & + & 7 \\
\hline
\end{tabular}

related to liver disease, but only $56 \%(9 / 16)$ of patients with hepatoma in this series had signs of hepatomegaly.

\section{Laboratory data}

In none of these 16 patients were liver function tests (alkaline phosphatase, aspartate aminotransferase, alanine aminotransferase) entirely normal. Hepatitis B surface antigen was checked on the first day of admission but only $75 \%(12 / 16)$ of specimens were positive. Of all the patients in which AFP was examined after tissue diagnosis, $69 \%(11 / 16)$ were positive.

Abdominal sonography was performed in all cases after establishment of the pathological diagnosis. In all except two, mass lesions were found in the liver. Coeliac angiography was done in one of these two cases and showed multiple hypervascular nodules in the liver. Liver-spleen CT demonstrated a positive finding in the other case.

\section{Survival}

The length of survival was recorded from the onset of the first symptom. Fifteen of $16(94 \%)$ patients died within one year. All died of hepatic failure, except one who succumbed to acute respiratory failure caused by lung metastasis with massive pleural effusion.

\section{Discussion}

Although necropsy examinations of patients dying of hepatocellular carcinoma have revealed evidence of metastasis in $50-75 \%$ of cases, ${ }^{3}$ it is distinctly unusual for the initial clinical presentation to be related primarily to the presence of metastasis, without overt evidence of hepatic involvement. ${ }^{4}$ Popper and
Schaffner ${ }^{5}$ divided hepatocellular carcinoma into frank, febrile, acute abdominal, icteric, metastatic, and occult types. Patients with the metastatic type, presenting with symptoms and signs related to distant metastasis without abdominal discomfort or palpable liver mass, are quite uncommon, comprising $1 \cdot 5-5.3 \%$ in different series. ${ }^{1}$

Earlier reports have stated that extrahepatic metastasis of primary carcinoma of the liver is uncommon. The lung and regional lymph node are the most common sites of metastasis. ${ }^{2}$ The central nervous system is an unusual site. ${ }^{467}$ The most common sites of metastasis causing CNS complications are the vertebrae and spinal epidural space. Of 19 such cases described by Collomb et al, ${ }^{7} 13$ patients had metastasis to the vertebrae and epidural space, one to the cranium, and five to the cerebrum. In Chang and Chen's series, ${ }^{6}$ vertebrae and the epidural space were involved in four cases, the cranium in two, and the cerebrum in one. A similar distribution was noted in our series.

The metastatic spread of primary hepatoma might initially result from invasion of the hepatic and portal veins. The regional lymph nodes, including periportal and peripancreatic nodes, were extensively involved. Pulmonary vascular metastasis then develops after the venous structures have been invaded and may be followed by widespread hematogenous spread with metastasis to the bone and brain. $^{8}$

Some explanations offered for the rarity of brain metastasis in patients with hepatoma include a rapidly fatal course, most patients having died within six months of the onset of symptoms. ${ }^{4}$ It is also possible that there have been more cases of metastasis to the nervous 
system, which perhaps have been overlooked or obscured by the symptoms of hepatic or other metabolic encephalopathy. ${ }^{910}$ When there is an absence of clinical manifestations, brain metastasis from primary hepatoma may be of little clinical significance. Most cases were found at necropsy, ${ }^{11}$ so there is a discrepancy between the incidence of clinical neurological complications and incidence at necropsy. ${ }^{6}$

In rare instances, an apoplectic onset of symptoms from a cerebral metastasis has been reported. ${ }^{6}$ The first patient in our series presented this way, with a history of progressive left arm weakness and numbness followed by sudden onset of left hemiplegia and disturbed consciousness.

Metastasis to the skull may be found either in the calvarium or in the base. When in the calvarium, it may be either extradural only, ${ }^{6}{ }^{12}$ as in cases 3 and 4, or may exhibit intracerebral extension ${ }^{6}$ with raised intracranial pressure or focal symptoms, as in case 2 of our series. When metastasis to the base of the skull occurs, the cranial nerves may be involved, without associated increase of intracranial pressure, as in cases 5, 6 and 7 of this series.

Hepatoma is believed to be an unusual primary among cases of spinal cord compression by metastatic tumours. In different series among white groups, $1 \cdot 2-3 \cdot 0 \%$ were reported. ${ }^{13-16}$ This is in contrast to the much higher incidence of $17 \cdot 1 \%$ among African cases. ${ }^{13}$ The nine cases reported here represent $15 \%$ of 59 cases of metastatic cancer to the spinal column (unpublished data) in our hospital series between 1981 and 1988 , which is close to that described in the African cases. ${ }^{13}$ The vertebrae have been reported by Carnahan ${ }^{11}$ and Green ${ }^{17}$ as the most common site of bone metastasis of hepatoma cells through the vertebral vein. From the overview of this series, the lumbar spine seems to be the most frequent site of vertebral metastasis, representing $44 \%$ (4/9) of cases. Clinically, all the patients with vertebral metastasis had a history of back pain or neck pain as the first symptom followed by symptoms of spinal cord compression. When the cervicothoracic spine was involved, myelopathy was the predominant symptom. When metastasis to the lumbar spine occurred, cauda equina syndrome was the main presentation. When sacrum metastasis developed, sphincter problems were the chief complaint.

Routine laboratory studies may provide little diagnostic help before biopsy. Although abnormal liver function may be detectable in the early stage, these findings do not differ from chronic liver disease. The most distinctive diagnostic laboratory test presently available for hepatoma is the immunoserological assay for AFP. The serologically positive percentage varied from $50 \%$ to $79.6 \%$ in different series. ${ }^{1}$ In our series, $69 \%$ of patients with hepatoma were found to be positive. Serum AFP levels have been shown to be correlated with liver weight in AFP-producing hepatoma. Sometimes it is negative or low in patients with early hepatoma. However, the measurement of serum AFP is useful in screening for early hepatoma. Even small hepatomas sometimes may present with elevated serum AFP level, which can be determined easily.

Liver ultrasound is a sensitive and easy method for the detection of hepatic tumours. Shen et $a^{18}$ reported a $93.9 \%$ (31/33) detection rate even with small hepatomas. Only a $54 \%$ detection rate was described by Kobayashi et al. ${ }^{19}$ In this series, $87.5 \%(14 / 16)$ of patients had a positive finding. Coeliac angiography is an established method for the diagnosis of hepatoma. A $77 \%$ detection rate was reported by Kobayashi et $a^{19}$ and the second case in our series was detected only by this method. Although it is sensitive and specific in detection of hepatoma, it is invasive and impractical for the follow up of high risk populations of patients.

It is well known that hepatoma runs a rapidly fatal course. In $83.5 \%$ of patients, death occurred within 6 months of the onset of symptoms. $^{5}$ In our series, $93.8 \%$ of patients died within one year. The average survival is 6.3 months after the onset of symptoms. The ultimate prognosis of patients with metastasis to the central nervous system is dependent on the natural history of the primary lesion.

The author would like to express his appreciation to Professor Jason L Starr for his detailed review of this manuscript and Miss Yun Shu for her excellent secretarial assistance.

1 Lin TY. Tumor of the liver. In: Bockus HL, ed. Gastroenterology, vol 3, 3rd edn. Philadelphia: W B Saunders, 1976:522-34.

2 Sung JL, Wang TH, Yu JY. Clinical study on primary carcinoma of the liver in Taiwan. Am $\mathcal{f}$ Dig Dis 1967;12:1036-49.

3 Benner EJ, Labby DH. Hepatoma: clinical experiences with a frequently bizarre tumor. Ann Intern Med 1961;54:620-35.

4 Ihde DC, Sherlock P, Winawer SJ, Fortner JG. Clinical manifestation of hepatoma. Am $\mathcal{\exists}$ Med 1974;56:83-91.

Popper H, Schaffner F. Liver Structure and Function. New York: McGraw-Hill, 1957:20-1.

6 Chang YC, Chen RC. Craniospinal and cerebral metastasis of primary hepatoma: a report of 7 cases. $\mathcal{f}$ Formosan Med Assoc 1979;78:594-604.

7 Collomb H, Sankale M, Dumas M, Ancelle JP. Neurological form of primary cancer of the liver: clinical and EEG study (Abstr). Excerpta Med 1970;23:377.

8 Zubler MA, Rivera R, Lane M. Hepatoma presenting as a retroorbital metastasis. Cancer 1981;48:1883-5.

9 Margolis S, Homcy C. Systemic manifestations of hepatoma medicine. 1972;51:381-91.

10 Asao H, Oji K. Hepatocerebral Degeneration. Springfield, MA: Charles Thomas Publisher. 1968:3-6.

11 Carnaban DS. Primary hepatoma with metastasis to a long bone. Radiology 1950;55:844-7.

12 Phadke JG, Hughes RC. Hepatocellular carcinoma with cranial metastasis and lyperglobulinemia. $\mathcal{f}$ Neurol Neurosurg Psychiatry 1981;44:1171-4.

13 Byrne MJ, Scheinberg MA, Mavligit G, Daiskins RL. Hepatocellular carcinoma: presenting with vertebral metastasis and radicular compression. Cancer 1972;30: 202-5.

14 Kennady JC, Stern WE. Metastatic neoplasms of the vertebral column producing compression of the spinal cord. Am $\mathcal{f}$ Surg 1962;104: 155-68.

15 Weight RL. Malignant tumor in the spinal extradural space: results of surgical treatment. Ann Surg 1963; 157:227-31.

16 Arsein CN, Simonescu MD, Horwath L. Tumors of the spine. A follow up study of three-hundred and fifty patients with neurosurgical considerations. Acta Psychia Neurol Scand 1959;34:398-410.

17 Greene JM. Primary carcinoma of the liver. Surg Gynecol Obstet 1939;69:231-6.

18 Shen JC, Sung JL, Yu JY, Wang TH, Su CT, Tsang YM. Ultrasonography of small hepatic tumor using highresolution linear-array real time instruments. Radiology 1984;150:797-802.

19 Kobayashi K, Sugimoto T, Makino H, et al. Screening methods for early detection of hepatocellular carcinoma. Hepatology 1985;5:1100-5. 